\title{
BODY MASS LOSS IN DRY SAUNA AND HEART RATE RESPONSE TO HEAT STRESS
}

PERDA DEMASSA CORPORAL EM SAUNA SECA E RESPOSTA CARDÍACA AO ESTRESSE POR CALOR

PÉRDIDA DEMASA CORPORAL EN SAUNA SECA Y RESPUESTA DE LA FRECUENCIA CARDÍACA AL ESTRÉS POR CALOR

Tomasz Boraczyński (Physical Education Professional)

Michał Boraczyński ${ }^{1}$

(Physical Education Professional)

Robert Podstawski

(Physical Education Professional)

Krzysztof Borysławski ${ }^{3}$

(Antropologist)

Krzysztof Jankowski

(Physical Education Professional)

1. Józef Rusiecki Olsztyn University College, Department of Physical Education, Olsztyn, Poland. 2. University of Warmia and Mazury, Department of Physical Education and Sport, Olsztyn, Poland.

3. University of Life Sciences, Department of Anthropology, Wrocław, Poland.

4. The Józef Piłsudski Academy of Physical Education, Department of Physical Education, Warsaw, Poland.

\section{Correspondence:}

Michał Boraczyński.

Department of Physical Education, Józef Rusiecki Olsztyn University College, ul. Bydgoska 33, 10-243 Olsztyn, Poland. michal.boraczynski@gmail.com

\section{RESUMO}

\begin{abstract}
Objectives: The aim of the study was to determine the effects of sauna-induced heat exposure on body mass loss (BML) and its relationships with basic anthropometric and physiological variables. Methods: The sample comprised 230 healthy adult males aged $21.0 \pm 1.08$ years (age range: 20.0-24.5 years). Body surface area $(B S A)$ was determined and two groups of individuals with high $B S A\left(B S A_{H} ; n=58\right)$ and low $B S A\left(B S A_{L} ; n=74\right)$ were extracted. The intervention consisted of two 10-min dry sauna sessions separated by a 5 -min interlude. Pre-, peri-, and post-sauna measures of nude body mass (BM) and heart rate (HR) were taken. Results: BML differed between BSA groups by $0.28 \mathrm{~kg}(74.81 \%)$. Absolute and relative BML most strongly correlated with BM and BSA $(p<0.001)$. Among the four considered height-weight indexes, the Quetelet I Index and Body Mass Index showed the strongest associations $(p<0.001)$ with BML whereas the weakest were with the Rohrer Index $(p<0.01)$ and Slenderness Index $(p<0.05)$. Compared with BML, differences in HR were relatively minor (from 9.90\% to $18.07 \%$ ) and a significant association was observed between BML and HR at rest $(p<0.01)$ and in $10^{\text {th }}$ and $20^{\text {th }}$ min of sauna bathing $(p<0.001)$. Conclusions: The magnitude of BML in healthy adult males after passive heat exposure was dependent on BM and concomitantly BSA. The physiological cost of dry saunainduced thermal strain (as assessed by BML and HR) is greater in individuals with high BM and BSA. BM and HR monitoring is also recommended in order to minimize the risk of homeostatic imbalance and cardiovascular events and this cohort should more frequently cool the body and consume a greater volume of fluids during sauna bathing. Evidence Level Il; Prospective comparative study.
\end{abstract}

Keywords: Finnish sauna; Heat stress response; Weight loss; Body Surface Area; Heart rate.

Objetivos: O objetivo do estudo foi determinar os efeitos da exposição ao calor induzidos pela sauna sobre a perda de massa corporal (BML) e sua relação com as variáveis antropométricas e fisiológicas básicas. Métodos: A amostra esteve formada por 230 homens adultos saudáveis de $21.0 \pm 1.08$ anos (média de idade: 20.0-24.5 anos). Foi determinada a área da superfície corporal (BSA) e separados em dois grupos de individuos com alta BSA (BSA $n=58)$ e baixa $B S A\left(B S A_{L^{\prime}} n=74\right)$. A intervenção consistiu em duas sessões de sauna seca de 10 minutos, separadas por um intervalo de 5 minutos. Foram tomadas as medidas pre-, peri-e posteriores à sauna, da massa corporal (BM) sem roupa e a frequência cardíaca (HR). Resultados: Entre os dois grupos de BSA, a BML diferenciou-se em $0.28 \mathrm{~kg}$ (74.81\%). A BML absoluta e relativa correlacionou-se com maior força com a BM e a BSA ( $p<0.001)$. Entre os quatro índices de tamanho-peso considerados, o Indice Quetelet l e o Indice de Massa Corporal mostraram as associações mais consistentes $(p<0.001)$ com a BML, enquanto que as mais fracas foram com o Índice Rohrer $(p<0.01)$ e o Indice de Magreza ( $p<0.05)$. Comparado com a BML, as diferenças no HR foram relativamente pequenas (de $9.90 \%$ a 18.07\%) e foi observada uma associação significativa entre a BML eo HR em repouso $(p<0.01)$ e em banho de sauna aos 10 e 20 minutos ( $p$ < 0.001). Conclusões: A magnitude da BML em homens adultos saudáveis após a exposição passiva ao calor dependeu da BM e da BSA. O custo fisiológico da tensão térmica induzida pela sauna seca (avaliada pela BML e o HR) é maior em indivíduos com alta BM e BSA. Também é recomendado o monitoramento da BM e HR para minimizar o risco de desequilíbrio homeostático e episódios cardiovasculares. Assim, esta população deveria refrescar seu corpo com maior frequência e consumir um maior volume de líquidos durante a sessão de sauna. Nível de evidência ll; Estudo comparativo prospectivo.

Descritores: Sauna finlandesa; Resposta ao estresse calórico; Perda de peso; Sauna; Área de superfície corporal; Frequência Cardíaca.

\section{RESUMEN}

Objetivos: El objetivo del estudio fue determinar los efectos de la exposición al calor inducidos por el sauna sobre la pérdida de masa corporal (BML) y sus relaciones con las variables antropométricas y fisiológicas básicas. Métodos: La muestra estuvo formada por 230 varones adultos saludables de $21.0 \pm 1.08$ años (rango de edad: 20.0-24.5 años). Se determinó el área de superficie corporal (BSA) y se separaron dos grupos de individuos con alta $B S A\left(B S A_{H,} n=58\right)$ y baja $B S A\left(B S A_{L}, n=74\right)$. La intervención consistió en dos sesiones de sauna seca de 10 minutos 
separadas por un intervalo de 5 minutos. Se tomaron medidas pre-, peri-y posteriores al sauna, de masa corporal (BM) sin ropa y la frecuencia cardíaca (HR). Resultados: Entre los dos grupos de BSA, la BML difirió en $0.28 \mathrm{~kg}(74.81 \%)$. La BML absoluta y relativa se correlacionó con más fuerza con la BM y la BSA $(p<0.001)$. Entre los cuatro índices de talla-peso considerados, el Índice Quetelet l y el Índice de Masa Corporal mostraron las asociaciones más fuertes $(p<0.001)$ con la BML, mientras que las más débiles fueron con el Índice Rohrer $(p<0.01)$ y el Índice de Esbeltez $(p<0.05)$. Comparado con la BML, las diferencias en el HR fueron relativamente pequeñas (de $9.90 \%$ a 18.07\%) y se observó una asociación significativa entre la BML y el HR en reposo ( $p<0.01$ ) y en baño de sauna a los 10 y 20 minutos ( $p<0.001)$. Conclusiones: La magnitud de la BML en varones adultos saludables posterior a la exposición pasiva al calor dependió de la BM y de la BSA. El costo fisiológico de la tensión térmica inducida por el sauna seco (evaluado por la BML y el HR) es mayor en individuos con alta BM y BSA. También se recomienda el monitoreo de BM y HR para minimizar el riesgo de desequilibrio homeostático y episodios cardiovasculares. Así, esta población debería refrescar su cuerpo con mayor frecuencia y consumir un mayor volumen de líquidos durante la sesión de sauna. Nivel de evidencia ll; Estudio comparativo prospectivo.

Descriptores: Sauna finlandés; Respuesta al estrés calórico; Pérdida de peso; Área de superficie corporal; Frecuencia cardiaca.

\section{INTRODUCTION}

Dry (Finnish) sauna is commonly administered for its therapeutic benefits, ${ }^{1}$ including improved resistance to infection, reduction of toxins, and inducement of psychological and physiological relaxation. 2,3 Sauna is routinely prescribed as an alternative non-pharmacological treatment for patients with certain lifestyle-related medical conditions to relieve symptoms and improve wellness. ${ }^{2}$ Compared with other whole-body heating therapies, it is well tolerated by the majority of healthy individuals over a wide age range. Sauna bathing is known to benefit the nervous, hormonal, cardiovascular systems ${ }^{5,6}$ by inducing a number of positive responses. ${ }^{4,7}$

The high temperatures of dry sauna naturally increase body temperature. To eliminate excess body heat, a number of autonomic responses occur including increased heart rate $(\mathrm{HR})$, elevated blood catecholamine concentration, vasodilatation (increasing to 6-8 L/min), intensified lung ventilation, and, most importantly, enhanced perspiration. ${ }^{4,6-9}$ Out of these, vapor evaporation by means of sweating and convective heat exchange (via air flow in lung alveoli and mucous membranes) are essential in situations of thermal stress. ${ }^{10,11}$ As the primary thermoregulatory mechanism for heat dissipation, sweating begins when body core temperature crosses a threshold of approximately $37^{\circ} \mathrm{C}$.

There is a history of athletes using dry sauna to induce passive dehydration for weight loss. ${ }^{12}$ Dehydration (body water deficit) is a physiological state that can have profound health implications. ${ }^{13}$ According to Cheuvront et al., ${ }_{1}^{14}$ the threshold for dehydration depends on the type and magnitude of body water deficit. In sauna, heat loads can reach $300-600 \mathrm{~W} / \mathrm{m}^{2}$ of skin surface area (skin temperature of $40-41^{\circ} \mathrm{C}$ ). This is compensated by reducing diuresis and increasing perspiration to a sweat rate of $0.5-1.0 \mathrm{~kg} / \mathrm{h}(8-17 \mathrm{~g} / \mathrm{min})$, where $10 \mathrm{~g} / \mathrm{min}$ is subject to evaporation representing a heat loss of generally $200 \mathrm{~W} / \mathrm{m}^{27,9}$ In the absence of fluid and electrolyte replacement, progressive dehydration and cardiovascular strain is induced by way of reduced cardiac filling and stroke volume, increased plasma tonicity, and decreased blood volume (hypovolemia). ${ }^{15,16}$ Even short periods of fluid restriction can lead to cognitive disorders such as reductions in alertness and concentration ability and increases in fatigue and headache. ${ }^{17}$

One of the simplest measures of dehydration status is body mass loss (BML). ${ }^{18}$ According to Shirreffs, ${ }^{19}$ a $1 \mathrm{~g}$ change in body mass (BM) represents a $1 \mathrm{~mL}$ change in water status. Other works in the literature confirm this exchange, where $1 \mathrm{~kg}$ of BML was found to be equivalent to $1 \mathrm{~L}$ of body water loss. ${ }^{8}$ The rate and extent of sauna-induced BML is associated with body volume and composition and therefore the mass of metabolically active tissue and skin surface area, of which the latter is the main source of heat dissipation. ${ }^{17,20}$ BML has also been used to assess the level of strain to heat stress, ${ }^{21}$ where metabolic heat production at rest is considered to be proportional to $\mathrm{BM}^{22}$ and body surface area (BSA). ${ }^{23}$ However, the applicability of other anthropometric variables to determine and predict BML, especially using easy-to-calculate weightheight indexes, is not well recognized even in asymptomatic populations. Furthermore, while the physiology of dehydration is well described, few studies have addressed the relationships between anthropometry (height, mass, surface area, and proportions), HR, and BML in response to sauna-induced heat exposure. ${ }^{24}$ This is unfortunate, as anthropometry provides a simple, inexpensive, and practical methodology particularly suitable in epidemiological or clinical research. Strengthening the knowledge base on these associations may have a number of theoretical and practical implications, particularly in developing recommendations on the safe use of dry sauna.

Therefore, the aim of the study was to determine the effects of sauna intervention on BML and its relationships with basic anthropometric measures and HR by examining a population of healthy adult males. We hypothesized that individuals differing in body size, specifically those with greater BM and BSA, would have substantially greater BML than those with relatively lower BM and BSA. Additionally, we posited that $H R$ and BML would show strong correlations in response to heat stress, where elevated $\mathrm{HR}$ may follow a linear relationship with increased BML.

\section{MATERIALS AND METHODS}

The study was performed with the prior consent of the Ethical Committee of the University of Warmia and Mazury (UWM) in Olsztyn, Poland. All subjects provided their written informed consent to participate in the study after the procedures were explained in full.

A cross-sectional design was adopted in which 230 healthy males aged $21.0 \pm 1.08$ years (age range: $20.0-24.5$ years) were randomly recruited from a population of UWM students by university advertisements (website and posters) and word of mouth. The participants were all volunteers. Sample characteristics are provided in Table 1. The inclusion criteria required: age $\geq 19$ years, body mass index (BMI) $\geq 18.5$ and $<30 \mathrm{~kg} / \mathrm{m}^{2}$ good health status (no medication requirements and free of cardiovascular or respiratory complications) and no sauna use for at least 6 months prior to the study (self-reported in a questionnaire). The participants were instructed to not intake alcohol for 48 hours before the start of the study. Exclusion criteria were: tobacco use, blood pressure $\geq 150 / 90 \mathrm{mmHg}$, resting $H \mathrm{H} \geq 90 \mathrm{bpm}$ after 5 min of sitting, or 
involvement in regular high-intensity ( $\geq 6$ MET) physical training $>2$ days per week (> 45 minutes) over the prior 6 months. The latter exclusion criteria were derived from the scientifically proven associations between exercise and sweat rate. ${ }^{25}$

The intervention was conducted in the morning (from 8:00 to 11:30 am). The study protocol involved two 10-min sessions of dry sauna interspersed with a 5-min rest period. The participants were instructed to drink at least $1 \mathrm{~L}$ of water one day before the procedure. On the day of the intervention they were to refrain from eating and drink only $0.5 \mathrm{~L}$ of mineral water $2 \mathrm{~h}$ before reporting to the sauna. Immediately before entering the sauna chamber the participants first urinated and then showered in $20^{\circ} \mathrm{C}$ water for $1 \mathrm{~min}$. Sauna temperature was maintained at $95^{\circ} \mathrm{C}$ (head level) with a relative humidity of $25-27 \%$. The rest interval involved a $2-\min 20^{\circ} \mathrm{C}$ shower with the remaining 3 min spent sitting in a temperature-controlled room $\left(22-23^{\circ} \mathrm{C}\right)$ before returning to the sauna chamber. After the second sauna session, the participants cooled down in a $10^{\circ} \mathrm{C}$ paddling pool for $30 \mathrm{~s}$ and sat in the temperature-controlled room for $5 \mathrm{~min}$. In order to limit potentially confounding effects, participants sat upright throughout the sauna sessions, no food or drink was ingested nor did they urinate or defecate.

Standing body height $(\mathrm{BH})$ was determined to the nearest $0.1 \mathrm{~cm}$ with a WB150 stadiometer (Tryb-Wag ZPU, Poland) before entering the sauna chamber. HR was measured with a RS800CX heart rate monitor (Polar Electro OY, Finland) at three time points: prior to sauna treatment to determine resting heart rate $\left(H \mathrm{R}_{0}\right)$, at the $10^{\text {th }}$ min of sauna bathing $\left(\mathrm{HR}_{10}\right)$ and at $20^{\text {th }}$ min of sauna bathing $\left(\mathrm{HR}_{20}\right)$. BM was measured to the nearest $0.1 \mathrm{~kg}$ with a BC-418MA Body Composition Analyzer (Tanita Corporation, Japan) before and after each sauna session (participants thoroughly dried themselves to remove all traces of sweat and water). The difference in BM across the two measures was quantified to determine BML as both an absolute and relative (percentage of BM) value and treated as an indicator of hypohydration status. In addition to BML, the four most commonly used weight-height indexes were also calculated: Quetelet I index (QI) - mass (g)/height (cm)², Quetelet II index $(\mathrm{BMI})$ - mass (kg)/(height [m] $)^{2}$, Rohrer's index (RI) - 1000x $\sqrt[3]{(\text { mass }[\mathrm{kg}]) /}$ (height $[\mathrm{cm}])$, and Slenderness index $(\mathrm{SI})$ - height $(\mathrm{cm}) / \sqrt[3]{ }($ mass $[\mathrm{kg}])$.
Total BSA was estimated according to Mosteller, ${ }^{26}$ where: BSA = $[(B M \times B H) / 3600] \times 0.5$. The Mosteller formula was selected based on the recommendations of Verbraecken et al. ${ }^{27}{ }^{27}$ who concluded it to be the most applicable in clinical research and practice as it is easy to use and valid in normal, overweight, and obese adults.

\section{Statistical analysis}

Basic descriptive statistics were calculated for all variables. The Shapiro-Wilk test was used to assess the normality of the dataset, confirming a normal distribution. The associations between the observed variables were determined with Pearson's correlation coefficients ( $r$ ). Based on $\mathrm{BSA}$, two outlier groups were extracted to compare the differences between individuals with high $\left(\mathrm{BSA}_{H}>M+0.5 \times S D ; n=58\right)$ and low $\left(B S A_{L}<M-0.5 \times S D, n=74\right)$ body surface area. This was performed in order to accommodate the large inter-individual variability in thermoregulatory responses to heat stress. ${ }^{28}$ Differences between these groups were analyzed with one-way analysis of variance (ANOVA). The level of statistical significance was set at 0.05. All calculations were performed using the Statistica 7.1 PL software package (StatSoft Inc., USA).

\section{RESULTS}

Considering the sample size, health status, and mean anthropometric characteristics, this sample can be treated as representative of a young adult male population. Large variation was observed in BML, from 0.2 to $1.1 \mathrm{~kg}$. This finding is reflected in the magnitude of the coefficient of variation (CV) for the entire sample (45.38\%), which was disproportionately larger compared with the CV of the other anthropometric measures (2.88-11.72\%) and HR (6.95-9.78\%). HR increased across the time points (mean increase by 56.6 bpm or $71.74 \%$ ) and was paralleled with increasing variation. (Table 1)

BML after the 20-min dry sauna bath correlated the strongest with BM and BSA ( $p<0.001$ ) (Table 1, Figures 1 and 2). Among the height-weight indexes, the Ql showed stronger correlations with BML than the more commonly used BMI $(p<0.001)$. Weaker correlations were observed with $\mathrm{RI}(p<0.01)$ while SI correlated with BML at the threshold of statistical significance $(p<0.05)$. Relative BML $(\%)$ correlated, from the strongest to

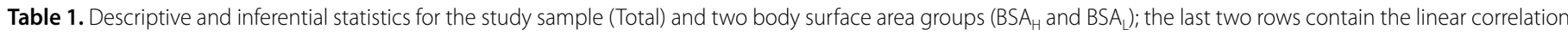
coefficients $(r$ ) between absolute and relative BML and the variables.

\begin{tabular}{|c|c|c|c|c|c|c|c|c|c|c|c|c|c|c|}
\hline \multirow{2}{*}{ Group } & \multirow{2}{*}{ Variables } & \multirow{2}{*}{$\begin{array}{c}\text { Age } \\
\text { (years) }\end{array}$} & \multirow{2}{*}{$\begin{array}{c}\mathrm{BH} \\
(\mathrm{cm})\end{array}$} & \multirow{2}{*}{$\begin{array}{l}\text { BM } \\
(\mathrm{kg}) \\
\end{array}$} & \multirow{2}{*}{$\begin{array}{l}\text { BSA } \\
\left(\mathrm{m}^{2}\right)\end{array}$} & \multirow{2}{*}{$\frac{\text { QI }}{(\mathrm{g} / \mathrm{cm})}$} & \multirow{2}{*}{$\frac{\text { BMI }}{\left(\mathrm{kg} / \mathrm{m}^{2}\right)}$} & \multirow{2}{*}{$\frac{\mathrm{RI}}{\left(\mathrm{g} / \mathrm{cm}^{3}\right)}$} & \multirow{2}{*}{$\frac{\mathrm{SI}}{(\mathrm{cm} / \sqrt[3]{\mathrm{kg}})}$} & \multirow{2}{*}{$\begin{array}{l}\text { BML } \\
(\mathrm{kg})\end{array}$} & \multirow{2}{*}{$\begin{array}{c}\text { BML } \\
(\%)\end{array}$} & \multirow{2}{*}{$\begin{array}{c}\mathrm{HR}_{0} \\
\text { (bpm) }\end{array}$} & \multirow{2}{*}{$\begin{array}{c}\mathrm{HR}_{10} \\
\text { (bpm) }\end{array}$} & \multirow{2}{*}{$\frac{\mathrm{HR}_{20}}{\text { (bpm) }}$} \\
\hline & & & & & & & & & & & & & & \\
\hline & Mean & 21.0 & 181.2 & 77.8 & 1.98 & 428.5 & 23.6 & 1.31 & 42.5 & 0.49 & 0.61 & 78.9 & 121.0 & 135.5 \\
\hline Total & SD & 1.08 & 7.25 & 9.11 & 0.147 & 39.45 & 1.91 & 0.114 & 1.23 & 0.204 & 0.204 & 5.48 & 9.83 & 13.25 \\
\hline \multirow[t]{4}{*}{$(n=230)$} & Min & 20.0 & 165.2 & 51.6 & 1.54 & 312.7 & 19.0 & 1.05 & 39.0 & 0.2 & 0.28 & 62 & 99 & 106 \\
\hline & Max & 24.5 & 203.1 & 108.1 & 2.46 & 540.0 & 29.5 & 1.68 & 45.7 & 1.1 & 1.29 & 90 & 143 & 164 \\
\hline & CV (\%) & 5.14 & 4.00 & 11.72 & 7.40 & 9.21 & 8.06 & 8.75 & 2.88 & 41.69 & 33.19 & 6.95 & 8.13 & 9.78 \\
\hline & Mean & 21.2 & 181.0 & 86.2 & 2.09 & 475.3 & 26.3 & 1.45 & 41.0 & 0.66 & 0.76 & 82.4 & 129.3 & 147.0 \\
\hline $\mathrm{BSA}_{\mathrm{H}}$ & SD & 1.30 & 6.66 & 8.52 & 0.138 & 32.46 & 1.29 & 0.078 & 0.73 & 0.190 & 0.165 & 4.99 & 8.10 & 10.80 \\
\hline$M+0.5 \times S D$ & Min & 20.0 & 169.2 & 73.4 & 1.88 & 426.7 & 24.6 & 1.29 & 39.0 & 0.4 & 0.51 & 65 & 100 & 106 \\
\hline \multirow[t]{3}{*}{$(n=58)$} & Max & 24.5 & 200.2 & 108.0 & 2.46 & 540.0 & 29.5 & 1.68 & 42.6 & 1.1 & 1.18 & 90 & 143 & 164 \\
\hline & CV (\%) & 6.11 & 3.68 & 9.89 & 6.60 & 6.83 & 4.93 & 5.38 & 1.78 & 28.60 & 21.74 & 6.06 & 6.26 & 7.35 \\
\hline & Mean & 20.9 & 180.9 & 71.3 & 1.90 & 393.5 & 21.8 & 1.20 & 43.66 & 0.38 & 0.53 & 74.96 & 113.2 & 124.5 \\
\hline$B S A_{L}$ & SD & 0.99 & 7.27 & 6.27 & 0.119 & 21.25 & 0.81 & 0.066 & 0.81 & 0.171 & 0.207 & 4.96 & 7.66 & 9.35 \\
\hline$M-0.5 \times S D$ & Min & 20.2 & 165.0 & 51.60 & 1.54 & 312.7 & 19.0 & 1.05 & 42.0 & 0.2 & 0.28 & 62 & 99 & 108 \\
\hline \multirow[t]{2}{*}{$(n=74)$} & Max & 23.4 & 201.2 & 88.4 & 2.23 & 439.8 & 22.7 & 1.35 & 45.7 & 1.0 & 1.29 & 87 & 134 & 148 \\
\hline & CV (\%) & 4.75 & 4.02 & 8.80 & 6.29 & 5.40 & 3.73 & 5.50 & 1.85 & 45.08 & 39.54 & 6.61 & 6.77 & 7.51 \\
\hline Differences & $(\%)$ & 1.62 & 0.04 & 20.87 & 9.94 & 20.81 & 20.71 & 20.58 & 6.05 & 74.81 & 45.09 & 9.90 & 14.26 & 18.07 \\
\hline $\mathrm{BSA}_{\mathrm{H}^{-}}-\mathrm{BSA} \mathrm{A}_{\mathrm{L}}$ & $p$ & 0.092 & 0.957 & 0.000 & 0.000 & 0.000 & 0.000 & 0.000 & 0.000 & 0.000 & 0.000 & 0.000 & 0.000 & 0.000 \\
\hline$r$ & $\mathrm{BML}(\mathrm{kg})$ & 0.089 & $0.591^{c}$ & $0.813^{c}$ & $0.797^{c}$ & $0.773^{c}$ & $0.588^{c}$ & $0.276^{b}$ & $-0.253^{a}$ & 1 & $0.965^{c}$ & $0.318^{b}$ & $0.534^{c}$ & $0.554^{c}$ \\
\hline Total $(n=230)$ & BML (\%) & 0.084 & $0.488^{c}$ & $0.650^{c}$ & $0.642^{c}$ & $0.615^{c}$ & $0.462^{c}$ & $0.209^{a}$ & -0.184 & $0.965^{c}$ & 1 & $0.319^{b}$ & $0.490^{c}$ & $0.507^{c}$ \\
\hline
\end{tabular}

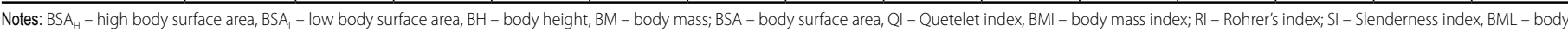
mass loss, $\mathrm{HR}_{0}$ - resting heart rate measured at baseline; $\mathrm{HR}_{10}$ - heart rate measured at $10^{\text {th }}$ min of sauna bathing; $\mathrm{HR}_{20}$ - heart rate measured at $20^{\text {th }}$ min of sauna bathing; ${ }^{\mathrm{a}} p<0.05{ }^{,}{ }^{\mathrm{b}} p<0.01,{ }^{\mathrm{c}} p<0.001$. 
weakest, with $\mathrm{BM}, \mathrm{BSA}, \mathrm{QI}, \mathrm{BH},(p<0.001)$, and BMI $(p<0.001)$ (Table 1). BML also significantly correlated with all HR measures, from baseline $\left(H R_{0} ; p<0.01\right)$ to $H R$ in the $10^{\text {th }}$ and $20^{\text {th }}$ min of sauna bathing $\left(H R_{10}\right.$ and $H R_{20}$, respectively; $p<0.001$ ). (Figure 3 )

The extraction of the two groups from the sample with the highest $\left(B S A_{H ;} ;=58\right)$ and lowest $\left(B S A_{L} ; n=74\right) B S A$ allowed for more detailed analysis in light of the fact that BML strongly correlated with BM and BSA. Significant differences between these two groups (excluding $B H$ ) were observed among all the anthropometric variables $(p<0.001$ ) (Table 1).

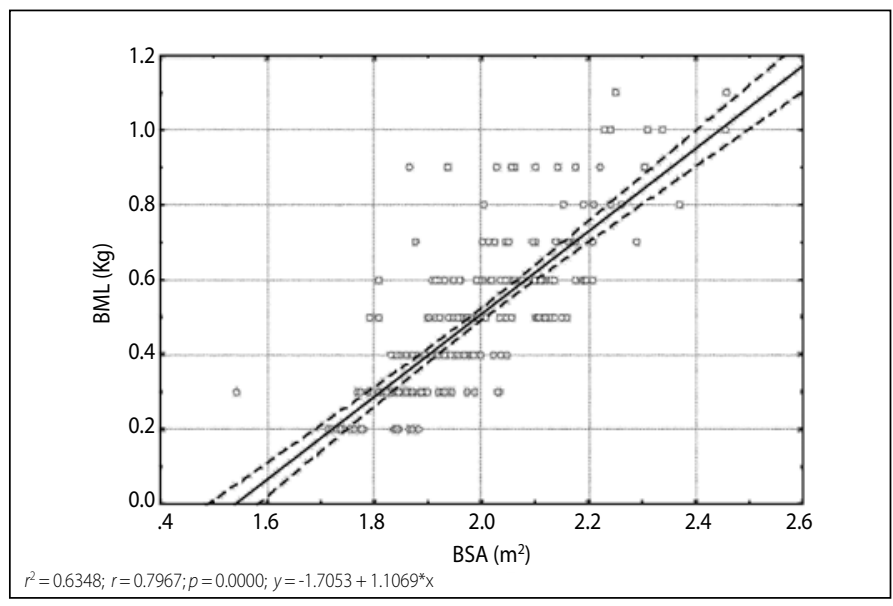

Figure 1. Relationships between body surface area (BSA) and sauna-induced body mass loss (BML) in young adult men $(n=230)$.

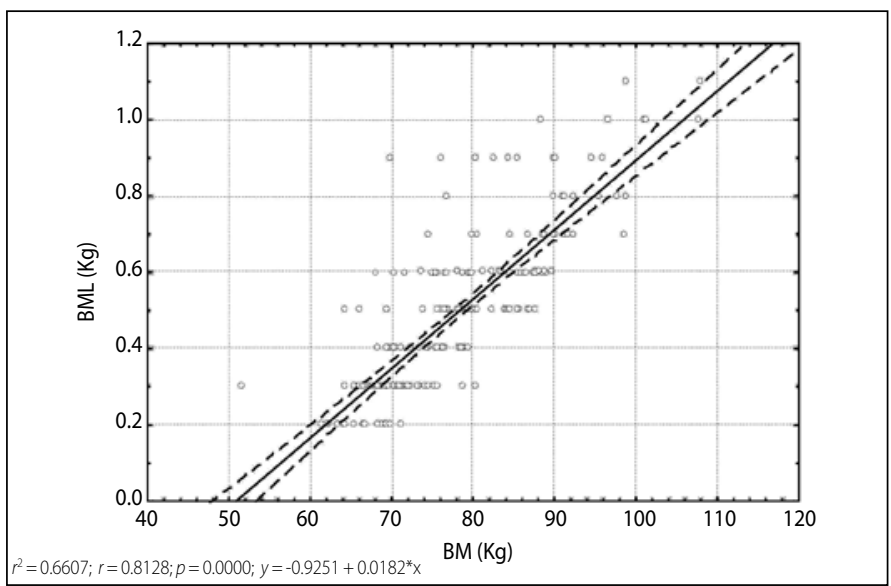

Figure 2. Relationships between body mass (BM) and sauna-induced body mass loss $(B M L)$ in young adult men $(n=230)$.

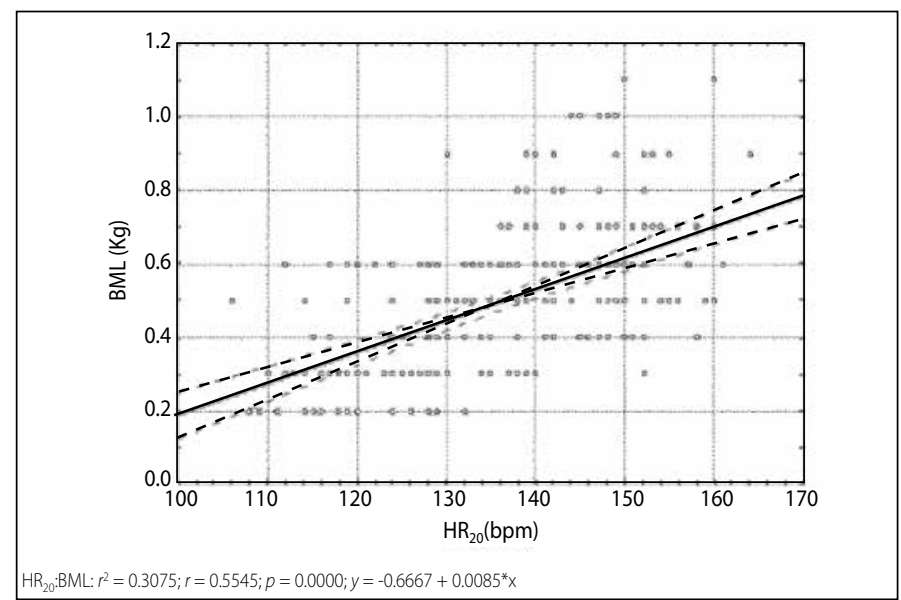

Figure 3. Relationships between heart rate measured at 20th min of sauna bathing (HR20) and sauna-induced body mass loss (BML) in young adult men $(n=230)$.
BMI for group BSA $A_{\mu}$ was above the accepted normal threshold $(26.3 \mathrm{~kg} /$ $\left.\mathrm{m}^{2}\right)$, where the majority $(n=39)$ presented BMl exceeding the normal range. ${ }^{29}$ When comparing groups $B S A_{H}$ and $B S A_{L}$ by percent differences, we found a difference of $0.04 \%$ for $\mathrm{BH}, 20.87 \%$ for $\mathrm{BM}$, and $45.09 \%$ for BML. (Table 1) Group BSA $A_{H}$ also lost significantly more body water (by 0.28 $\mathrm{kg}$ or $74.81 \%)$ than $\mathrm{BSA}_{\llcorner}(p=0.000)$. Compared with the magnitude of BML, the differences in HR were relatively minor (from $9.90 \%$ to 18.07\%) albeit statistically significant $\left(p<0.01\right.$ at rest $\left[\mathrm{HR}_{0}\right]$ and $p<0.001$ in the $10^{\text {th }}\left[\mathrm{HR}_{10}\right]$ and $20^{\text {th }}\left[\mathrm{HR}_{20}\right]$ min of sauna bathing).

\section{DISCUSSION}

The main goal of our study was to determine the effects of sauna-induced heat exposure on BML and investigate any relationships between BML, other basic anthropometric characteristics, and HR in healthy adult males. A review of the literature did not find any congruent empirical research using similar conditions. Specifically, we hoped to document the magnitude of BML in response to a controlled 20-min dry sauna bath, confirm the potential relationships between the anthropometric measures and $\mathrm{HR}$ with $\mathrm{BML}$, and determine which anthropometric characteristic most strongly correlated with BML. In view of the documented risks associated with sauna use, evidence suggests that BML and HR can serve as useful indicators in preventing dehydration, hyperthermia, and other associated medical conditions. ${ }^{8,19}$

Sweating, as the most efficient mechanism of reducing body temperature, leads to a significant reduction in body water, BM, and plasma volume. ${ }^{5,20}$ The risk of dehydration is particularly great during sauna bathing, where the mean loss of water is $0.40-0.60 \mathrm{~kg}$ in a typical sauna bath. ${ }^{3}$ Pilch et al. ${ }^{30}$ measured water loss by BML, finding decreases of 0.78 and $0.72 \mathrm{~kg}$, respectively, after a $3 \times 15$ min dry sauna bath. In our study, the BML of the total sample amounted to $0.49 \mathrm{~kg}$ (a decrease of $0.61 \%)$, whereas for groups $B S A_{H}$ and $B S A_{\llcorner}$this was $0.66 \mathrm{~kg}(0.76 \%)$ and $0.38 \mathrm{~kg}(0.53 \%)$, respectively.

In general, heat loss at rest is proportional to the gradient between the skin (and therefore the BSA available for heat exchange) and environment. ${ }^{23}$ BSA is a measure frequently used in physiological and clinical research to normalize various functional variables with respect to differences in body size and conformation. Additionally, total body water and extracellular water were demonstrated to be more closely related to BSA than BM. ${ }^{31}$ Our results strengthen this finding, with very similar correlations observed between BML and BSA ( $r=0.797)$ and BML and BM ( $r=0.813)$. It is important to note that the individual differences in susceptibility to heat stress (sweating patterns, thermoregulatory efficacy, physical endurance, hydration status) can modulate water loss and therefore BML. For these reasons, we attempted to control for the latter two factors by recruiting a homogeneous untrained sample and having the participants follow a specific hydration protocol determining the time, type, and amount of fluid intake.

Among the four considered height-weight indexes, we found that the Quetelet I (QI) and II (BMI) indexes were most strongly associated $(p<0.001)$ with sauna-induced BML (absolute and relative) whereas the weakest correlations were with the Rohrer Index (Rl; $p<0.01)$ and Slenderness index $(S \mid ; p<0.05)$. Unfortunately, there is a lack of resear$c h$ in the literature assessing the relationships between various these height-weight indexes and other anthropometric measures with BML apart from a similar study performed by the present group of authors. ${ }^{24}$ In this study, increased BMI was accompanied by a disproportionate increase in BML (in absolute $\mathrm{kg}$ and as a relative percentage of total $B M$ ) in response to a sauna intervention. It was inferred that individuals with high BMl are more susceptible to dehydration and should therefore consistently replenish fluids during sauna bathing. A similar conclusion can be drawn on the basis of the present findings, although the division 
criterion was dichotomizing the sample by BSA. Using this criterion, individuals with unhealthy levels of body fat (based on $\mathrm{QI}, \mathrm{BMI}, \mathrm{RI}, \mathrm{SI}$ ) and greater BSA lose more body water.

The physiological loss of BM is undeniably associated with hemodynamic function, in which $\mathrm{HR}$ is considered to be a primary indicator of metabolic rate. In general, the level to which HR increases depends on individual tolerance to thermal strain. Many studies have adopted changes in HR (and rectal temperature) to determine a physiological strain index to active and passive heat exposure. ${ }^{32-34}$ Existing research has found that a moderate dry sauna bath can increase HR to approx. 100 bpm in accustomed subjects and to approx. 160 bpm during intense dry sauna bathing in unaccustomed subjects. ${ }^{7,30}$ Besides increased $H R$, cardiac output may also rise by $6-7 \mathrm{~L} / \mathrm{min}$ (by $60 \%$ to $70 \%$ in relation to the increase in $\mathrm{HR}$ ) although cardiac stroke volume has been found to remain constant or slightly increase in response to thermal stress. ${ }^{35}$ Pilch et al. ${ }^{30}$ (reported that dry sauna-induced heat exposure led to an increase of HR from $66.6 \mathrm{bpm}$ to $126 \mathrm{bpm}$ (or 89.26\%). This is in agreement with our results, where sample-wide HR increased by $71.74 \%$ from $78.9 \mathrm{bpm}\left(\mathrm{HR}_{0}\right)$ to $135.5 \mathrm{bpm}\left(\mathrm{HR}_{20}\right)$ and that $\mathrm{HR}$ was significantly larger in group $\mathrm{BSA}_{H}$ than $\mathrm{BSA}_{\mathrm{L}}$ (147.0 bpm vs. 124.5 bpm, respectively; $p=0.000$ ). We also found strong correlations between $\mathrm{HR}_{10}$ and both absolute and relative BML $(r=0.534, r=0.490$, respectively; $p<0.001)$ and even stronger correlations between $\mathrm{HR}_{20}$ and both absolute and relative $\mathrm{BML}(r=0.554, r=0.507$, respectively; $p<0.001)$.

\section{CONCLUSIONS}

The magnitude of BML in healthy adult males after a two-part dry sauna intervention (at $95^{\circ} \mathrm{C}$ and $25-28 \%$ relative humidity) was dependent on BM and concomitantly BSA. Among the weight-height indexes, the strongest and weakest associations with sauna-induced BML were the Quetelet I index (QI) and Slenderness index (SI), respectively. Males with greater BM and BSA lost significantly more body water (as determined by absolute and relative BML) than those with less BM and BSA, indicating that individuals with greater BM and BSA are more susceptible to dehydration and hyperthermia and should therefore more frequently cool the body and consume a greater volume of fluids during sauna bathing. Similarly, the physiological cost of dry sauna-induced heat exposure (as assessed by BML and HR) is higher in individuals with greater $\mathrm{BM}$ and BSA. For this reason, such individuals may benefit from frequent monitoring of $\mathrm{BM}$ and $\mathrm{HR}$ in order to minimalize the risks of homeostatic imbalance and cardiovascular events. Based on our findings, we do not recommend high-BM and -BSA individuals use dry sauna $\left(95^{\circ} \mathrm{C}\right.$, relative humidity $25-27 \%$ ) for more than $2 \times 10$ min sessions. Additional study on the effects of dry sauna bathing by anthropometry may help improve heat stress prediction and also aid in understanding the principles of heat transfer in these conditions.

All authors declare no potential conflict of interest related to this article.

AUTHORS' CONTRIBUTIONS: Each author made significant individual contributions to this manuscript TB (0000-0002-7851-666X)*: intellectual concept of article and elaboration of the entire research project, writing of the article, data analyses, revision of article; MB (0000-0001-6517-4034)* literature search, writing of the article, data analysis, revision of article; RP (0000-0002-1492-252X)*: data collection, revision of article; KB (0000-0002-6290-1192)*: statistical analysis, revision of article; KJ (no ORCID): revision of article as well as all of the intellectual content of the article. All authors contributed to the intellectual concept of the study. ${ }^{*} \mathrm{ORCID}$ (Open Researcher and Contributor ID).

\section{REFERENCES}

1. Scoon GS, Hopkins WG, Mayhew S, Cotter JD. Effect of post-exercise sauna bathing on the endurance performance of competitive male runners. J Sci Med Sport. 2007;10(4):259-62.

2. Biro S, Masuda A, Kihara T, Tei C. Clinical implications of thermal therapy in lifestyle-related diseases. Exp Biol Med (Maywood). 2003;228(10):1245-9.

3. Hedley AM, Climstein M, Hansen R. The effects of acute heat exposure on muscular strength, muscular endurance, and muscular power in the euhydrated athlete. J Strength Cond Res. 2002;16(3):353-8.

4. Hannuksela ML, Ellaham S. Benefits and risks of sauna bathing. Am J Med. 2001;110(2):118-26.

5. Blum N, Blum A. Beneficial effects of sauna bathing for heart failure patients. Exp Clin Cardiol. 2007;12(1):29-32

6. Pilch W, Szyguła Z, Torii M. Effect of the sauna-induced thermal stimuli of various intensity on the thermal and hormonal metabolism in women. Biol Sport. 2007;24(4):357-73.

7. Leppäluoto J, Tuominen M, Väänänen A, Karpakka J, Vuori J. Some cardiovascular and metabolic effects of repeated sauna bathing. Acta Physiol Scand. 1986;128(1):77-81.

8. Sawka MN, Pandolf KB. Effects of body water loss on physiological function and exercise performance. Perspect Exerc Sci Sports Med. 1990;3:1-38.

9. Kukkonen-Harjula K, Kauppinen K. Health effects and risks of sauna bathing. Int J Circumpolar Health 2006;65(3):195-205

10. Brouns F. Heat-sweat-dehydration-rehydration: a praxis oriented approach. J Sports Sci. 1991;9(1 Suppl.):143-52.

11. Charkoudian N. Skin blood flow in adult human thermoregulation: how it works, when it does not, and why. Mayo Clin Proc. 2003;78(5):603-12.

12. Schoffstall JE, Branch JD, Leutholtz BC, Swain DP. Effects of dehydration and rehydration on the one-repetition maximum bench press of weight-trained males. J Strength Cond Res. 2001;15(1):102-8.

13. Campbell N. Dehydration: why is it still a problem? Nurs Times. 2010;107(22):12-5.

14. Cheuvront SN, Fraser CG, Kenefick RW, Ely BR, Sawka MN. Reference change values for monitoring dehydration. Clin Chem Lab Med. 2011;49(6):1033-7.

15. Institute of Medicine. Dietary Reference Intakes: Water, Potassium, Sodium, Chloride, and Sulfate. Food and Nutrition Board. Washington, D.C.: The National Academies Press, 2004.

16. Kenney WL, DeGroot DW, Holowatz LA. Extremes of human heat tolerance: life at the precipice of thermoregulatory failure. J Therm Biol. 2004;29(7):479-85.

17. Maughan RJ. Impact of mild dehydration on wellness and on exercise performance. Eur J Clin Nutr. 2003;57(2 Suppl.):S19-23

18. Pilch W, Szyguła Z, Zychowska M, Gawinek M. The influence of sauna training on the hormonal system of young women. J Hum Kinet. 2003;9:19-30
19. Shirreffs SM. Markers of hydration status. J Sports Med Phys Fitness. 2000;40(1):80-4

20. Maughan RJ, Shirreffs SM, Watson P. Exercise, heat, hydration and the brain. J Am Coll Nutr. 2007;26(5 Suppl):604S-12S

21. Sawka MN, Coyle EF. Influence of Body Water and Blood Volume on Thermoregulation and Exercise Performance in the Heat. Exerc Sport Sci Rev. 1999;27(1):167-218

22. Anderson GS. Human morphology and temperature regulation. Int J Biometeorol. 1999;43(3):99-109.

23. Austin DM, Lansing MW. Body size and heat tolerance: a computer simulation. Hum Biol. 1986;58(2):153-69

24. Havenith G. Human surface to mass ratio and body core temperature in exercise heat stress - a concept revisited. J Therm Biol. 2001;26(4):387-93.

25. Podstawski R, Boraczyński T, Boraczyński M, Choszcz D, Mańkowski S, Markowski P. Sauna-Induced Body Mass Loss in Young Sedentary Women and Men. Sci World J. 2014;17:1-7.

26. Cheung SS, McLellan TM. Heat acclimation, aerobic fitness, and hydration effects on tolerance during uncompensable heat stress. J Appl Phys (1985). 1998;84(5):1731-9.

27. Mosteller RD. Simplified calculation of body-surface area. N Engl J Med. 1987;317(17):1098.

28. Verbraecken J,Van de Heyning P, De BackerW, Van Gaal L. Body surface area in normal-weight, overweight, and obese adults. A comparison study. Metabolism. 2006;55(4):515-24

29. Mehnert P, Bröde P, Griefahn B. Gender-related difference in sweat loss and its impact on exposure limits to heat stress. Int J Ind Ergon. 2002;29(6):343-51.

30. WHO. World Health Report 2002. Reducing risks, promoting healthy life. World Health Organization, Geneva 2002. [Acesso em 2018 abr 02]. Disponível em: www.who.int/whr/2002/chapter4/en/index4.html

31. Pilch W, Szyguła Z, Palka T, Pilch P, Cison T, Wiecha S. Comparison of physiological reactions and physiological strain in healthy men under heat stress in dry and steam heat saunas. Biol Sport. 2014;31(2):145-9.

32. Englesbe MJ, Lee JS, He K, Fan L, Schaubel DE, Sheetz KH, et al. Analytic morphomics, core muscle size, and surgical outcomes. Ann Surg. 2012;256(2):255-61.

33. Moran DS, Shitzer A, Pandolf KB. A physiological strain index to evaluate heat stress. Am J Physiol. 1998;275(1 Pt 2):129-34.

34. Frank A, Belokopytov M, Shapiro Y, Epstein Y. The cumulative heat strain index - a novel approach to assess the physiological strain induced by exercise-heat stress. Eur J Appl Physiol. 2001;84(6):527-32.

35. Pokora I, Żebrowska A. Application of A Physiological Strain Index in Evaluating Responses to Exercise Stress-A Comparison Between Endurance and High Intensity Intermittent Trained Athletes.J Hum Kinet. 2016;50(1):103-14.

36. Prystupa T, Wołyńska A, Ślężyński J. The Effects of Finish Sauna on Hemodynamics of the Circulatory System in Men and Women. J Hum Kinet. 2009;22(1):61-8. 